\section{SOI: 1.1/TAS DOI: 10.15863/TAS International Scientific Journal Theoretical \& Applied Science}

p-ISSN: 2308-4944 (print) e-ISSN: 2409-0085 (online)

Year: $2016 \quad$ Issue: 9 Volume: 41

Published: $30.09 .2016 \quad$ http://T-Science.org

SECTION 29. Literature. Folklore. Translation Studies.

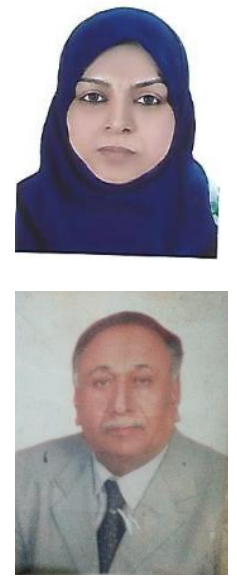

Raghad Abed Abu Jassim Master General Directorate of

AL_Najaf Al_Shrif Education Raghad_75@yahoo.com

Abed al-Kadem Mohsen al-Yassiri Proffesor

Collage of Education for girls University of Kufa

\title{
THE DIRECT SPEECH VERBS IN VERSE OF RELIGIONS CONVERSATION
}

\begin{abstract}
Language communication consider as a complicated human active ; it requires to do different language skills; in different ways for the purpose of showing the ability and communication efficiency; and perhaps the most important theses submitted in this field (the theory of speech verbs ) it considers one of most prominent achievements in the field of linguistic studies, especially deliberative which considers in the recent time the pole which rounds in his course the different deliberative studies. The search of the direct speech verbs in verse of religions conversation in the Holy Quran has studied according to division which Dr. Mahmood Ahmad Nahla has discussed it because it agrees with Arabic language characteristic, benefiting in this from the division of Austin and Searle and their standards for the purpose to exit with (Arabic theory of speech verbs) he divided it to five parts is (rhythms, applications, information, obligations, and expressions) all of these located under the class of direct speech verbs and this which we apply in our study to verse of religions conversation.

Key words: religions, language, direct speech verb.

Language: English

Citation: Jassim R, Mohsen al-Yassiri A (2016) THE DIRECT SPEECH VERBS IN VERSE OF RELIGIONS CONVERSATION. ISJ Theoretical \& Applied Science, 09 (41): 26-39.

Soi: http://s-o-i.org/1.1/TAS-09-41-4 Doi: crossef http://dx.doi.org/10.15863/TAS.2016.09.41.4
\end{abstract}

The speech verb:

The definition of speech verb is each vocalized raises as effective achievement indicative formal system in addition it considers as grammatical material active entreats speech verb to achieve fulfillment purposes as demand, order, promise, and effective goals linked to response of receiver act as rejection and acceptance and then it is act aspires to be effective act which mean it aspires to be the impact in speaker social or institutionally and then achieve something .Shukri Alambkhot defined it :speech (which mean lexical and grammatical structure) which construction strength progress it and which mean by this making behavioral or mental effective and say something, which mean making a certain act and behavior, and in another meaning pronunciation with something is getting effective attachment so it is a pronunciation represent meaningful performance act effect in receivers to do something, it is linguistic activity it is aim is changing the reality and searching in it, it is search about interesting in deliberative linguistic it is one of the biggest basis. since it is the issue of dialogue between us for religions occupied a large area in intellectual, international, Islamic, ancient and contemporary studies. This theory has roots at Arabic scholars in difference of their specializations, but it didn't' study for itself, but it came with signals in difference researches and it might most notably investigation of news and composition but in the west Austin consider establishment stage, but Searle represents maturity and classification stage which basing on clear method. As Austin distinguished between three types of speech verbs :

1-Speech verb(linguistic verb): it means releasing meaningful vocalizations in useful sentences and right grammatically, it consists known linguistic levels, it consists of linguistic voices arranged in right linguistic structure which leads to special meaning, which Austin called it verbs it is: the voice verb, structural verb and meaningful verb.

2-Achievement verb(the verb included speech):is achievement intentional verb from theory, which mean is achievement things and social verb 
with words it consider to be verb completed including speech and it isn't verb resultant from speech when I say :I promise it mean I am doing promise verb itself.

3-Effective verb (verb resultant from speech) it is impact which achievement verb causes in speaker or listener, which mean the impact represents the result of speech.

Austin sees that achievement speech verb is known, but effective speech verb isn't agreement and the purpose of it reaching to the aim and produce the consequence of saying. we might find in one pronunciation three types of speech verbs.

The efforts of Austin and Searle consider important and effective especially the studying of construction verbs which connecting with direct forms and conditions of its using in speech like report and question, it considers the basic section for its analyzing work. and then reaching to difference using ways to communication and telling speech verb to receiver. Islamic scholars pointed out in their researching to direct and indirect speech verbs and distinguished between them the scholars of assets and meaning exerted a big effort in their determination, so we find at them a clear realization to the concept of speech verbs which related to direct or letter or original meaning, besides to their knowledge what falls under it from indirect meanings or what called exiting from apparent appropriate . it might the speakers using to direct speech verbs coming from his desire in reaching his intent and commissioning the receiver with something or directed it with his favor from one side and deported it from damage from other side and then fulfillment the aim of speech.

\section{1- The Rhythms :}

It means the rhythm of verb with saying, compare its pronounce in the presence, and the verb falls in it just pronounce it, and this kind expands to include the verb of buying, sale, gift, recommendation, awsuit, denial, acknowledgment, abdication about the right, marriage, divorce, agency and similar, Searle called it advertisements.It requires for its authenticity difficult conditions was placed by jurists, it might doesn' $t$ ' different from the conditions of Austin and Searle, the most important of them:

1-the speech be clear significance on the require without frank.

2-to be followed to language usage, for each verb has especial pronunciation, sale verb different from recommendation verb and so.

3 -each of speaker and listener to be know what passed from other and agree on it.

4-the rhythm of verb to be complete . 5-the tense of verb present or future to be pronounce and meaning, or meaning only, if its pronounce and meaning are past, it will be news.

6- as for devotion condition in work is requiring to all speech verbs.

It should be noted now these conditions don't specialize to rhythms only but it is general conditions to perform speech verbs successful performance.

(God received the covenant of the prophets, "Inasmuch as I have given you of scripture and wisdom; should a messenger come to you verifying what you have, you shall believe in him, and support him." He said, "Do you affirm My covenant and take it upon yourselves?" They said, "We affirm it." He said, "Then bear witness, and I am with you among the witnesses. Whoever turns away after thatthese are the deceitful. Do they desire other than the religion of God, when to Him has submitted everything in the heavens and the earth, willingly or unwillingly, and to Him they will be returned? Say, "We believe in God, and in what was revealed to us; and in what was revealed to Abraham, and Ishmael, and Isaac, and Jacob, and the Patriarchs; and in what was given to Moses, and Jesus, and the prophets from their Lord. We make no distinction between any of them, and to Him we submit.

" Whoever seeks other than Islam as a religion, it will not be accepted from him, and in the Hereafter he will be among the losers. How will God guide a people who disbelieved after having believed, and had witnessed that the Messenger is true, and the clear proofs had come to them? God does not guide the unjust people)

These verses have many verbs which represent rhythms as acknowledgment, judgment and denial, acknowledgment represent in ((they said we decided)) and ((say we believed in Allah and what descended on Ibrahim......we don't differentiate between anyone of them and we to him Muslims)), the speech verbs which completed with these pronunciations are acknowledge and recognition with what Almighty asked from them and which representation with recognition with prophecy with all prophets without differentiate between anyone of them, the recognition of prophets with the books of all prophets and their religions, it gave us effective represents perfection and faith, because the prophets admitted about this you are their followers you should follow them in this too, as for judgment represents in ((whom take over after this those are libertines)), and ((whom wants other than Islam religion won't accept from him and he is in afterlife from losers)), it represents his achievement strength in issuing the judgments from God in the matter of whom infringed approval of the prophets, his almighty issued judgments in them because he is the owner of authority and this not need known linguistic, he ruled on them with losing and libertines which mean the exiting from the order of 
God, and he pointed out to them with ((those))significance to the moral demission, they are far from the satisfaction of God to their infraction and their exiting from order they are far from its recompense, as for denial represents in((other than the religion of Allah they wanted and to him who in heavens and earth believed willingly and unwillingly)) and ((how Allah guides people who disbelieved after their faith)), the completed speech verbs in this sayings represents in the denial on whom wants to fellow religion than religion of God and it is the right religion which prophets and apostles approved it, who live in heavens and earth believed it, $\{$ who $\}$ is using for human.

From other verses which included acknowledgment and denial ,

(Say, "Who provides for you from the heaven and the earth? And who controls the hearing and the sight? And who produces the living from the dead, and produces the dead from the living? And who governs the Order?" They will say, "God." Say, "Will you not be careful?" Such is God, your Lordthe True. What is there, beyond the truth, except falsehood? How are you turned away?)

The prophet Mohammed (peace be upon him) reminded them blessing of God on them, in the form of question then his Almighty when reminded this detail, he reminded after it words altogether, his saying ((who manages the matter))and that because sections of the management of God in the upper world, the bottom world, souls world, bodies world and things without end, he reminded it all, when he reminded some of these details, he followed assuredly with total words to refer on the rest then God explained that prophet Mohammed (peace be upon him), if he asked them about the planner of these situations, they would say Almighty God, and this mean that addressees in this speech was knowing God and was admitting him, they who said in their worship to fetishes, it is making us closer to God and it is our intercessor to God, they was knowing these fetishes don't work and don't harm, thereupon he said to his prophet(peace be upon him): ((say won`t believe!)), \{won`t believe\}this mean you make these fetishes partners to God in worship, with yours recognition that all welfare in the life and afterlife was happened by the mercy of God, and yours recognition these fetishes don't work and don't harm, in their answer achievement verb which came approval about what prophet reminded them about, then following with another achievement show, is denial, if he denied on them their worship to the fetches after their recognition and admitting with God.

We notice from this all, these verbs have caused changing in the current situation, it available all conditions which the studiers identified, in it available intent and reporting intention, its achievement power has changed according to the speakers class and their psychological state .

\section{2-Applications:}

This kind includes speech verbs which significances to the demand, regardless to its form, and the direction of conformity in it, is being from the world $t$ to words, as for achievement purpose of it, is the effective in the speakers to do something, or telling about something and order application includes suffice form, and prevention in different form, question and call. Order mean: the form which requires from him on the way of snobbery, but on condition it isn't need from it the threat or overstated or so...the snobbery was required in order application, which mean the student conceived himself high, even he doesn't in reality, also pray for and petition exit to what is on the way undergo and equality, it is using form which refers to the demand of speaker from listener to do something on the way of snobbery, whether it is snobbery significant at God, like the snobbery of scholars on ignorant, and the equitable ruler on his people or it was height significant at people like the height of rich on poor and something like that, the command has many forms is :

The command verb in the form of (Do), the present verb with (L) for command, the name of command verb, deputy source of command verb, command name like you commanded with something, pronunciation specialized for obligatory like: ought, should, must and other. Sentence semi, formulas morphological like passive voice besides the news forms from sender with authority, it may command verb comes tacitly then we understand it from text. The scholars differentiate in the using of command, it isn't enough formulas morphological alone in its definition, it must get aid from the text and clues in this, besides to the class of sender and whom send to and this what enter in deliberative, the matter isn`t linguistic but deliberative linguistic, linguistic situation isn't the only standard, it should be related to the class of sender, because it is changing formulate indication from command to other thing. In this directing with using of command form looks doesn't belong to linguistic modest only, but it is agreement with authority of sender on condition it doesn't disagree with authority higher than from his authority......and it is religions teaching authority. We find command verb in the religions conversation verses significantly, and it led achievement role to effect in the receiver, especially the verb (say)it repeated in these verses significantly, its coming shapes consecutive from speech verbs, the pronounce with him Almighty God by Gabriel (peace on him), and the pronounce for him is the

prophet Mohammed(peace be upon him), it will be pronounced after received to pronunciation, this verb (say)it is command verb from execution verbs fellow it another verbs, especially order achievement 
verbs which represent command, call and question (Messengers before you were ridiculed, but those who mocked them became besieged by what they ridiculed. Say, "Travel the earth and observe the final fate of the deniers). The verb (say) is command verb, it is more coming in the conversation situation in Holy Quran, it may its using in this situation to assured the speech which preceded it, God warned the people , and said to his prophet say to them don't be proud about what you find in this life and you reached it with its pleasures and desires, walk in the earth to know the truth about what the prophet told you, the punishment of those who lied the prophets .when you walk on the earth and travel in the countries it may to see those archaeology. The order of God came to direct his prophet in requiring from them walking in the earth and see remnant of mockers with prophets, to investigation achievement purpose represents in emphasis what mentioned before, effective verb is warning them, if they don't leave what are they, they will experience the punishment, besides the entertainment of his prophet (peace be upon on him), the Holy Quran follow the prophet in all his steps, the Holy Quran indicate hypocrisy of the people of the book in many positions, ( Some of the People of the Book say, "Believe in what was revealed to the believers at the beginning of the day, and reject it at its end, so that they may return). This speech is transported speech from Jewry people, their sayings came as order represents achievement verbs (believed, disbelieved), its achievement power is the questioning, and represents in deceiving the Muslims, and their skepticism in their doctrine, the pretence with faith in the first of day, and then disbelieved in the end of the day, it is trick which may suspect some of weak minded, especially Arabian who believed that the people of book are more knowledge in the religions and the books, if they see, they will believe and then disbelieved after that, they will tempted them not to enter in Islam for their believing that the people of the book found shortage in it so they retracted from their believing in it, and this represents effective verb. The prevention consider one of applications which effect in the speaker to leave verb or saying, it is one of construction methods, it mean ' it request the desist from the verb on the way of snobbery and compulsion' it is prevention of order, it has two conditions, they are :

_ The snobbery .

_ committed the speaker with it .

If one of these conditions misfire, the prevention will exit from its original to continuous purpose which the text impose it, as the threat, pray for, contact and the like, it has only one form it is the present which coupled with prevention(No), the prevention which opposite to command 'and agree with command in the matter both of them it must has snobbery and both of them related with other, it isn ` $t$ possible human command himself or prevent himself, and must be consider the state of the subject of being need for them, and differentiate in the matter both of them specialized in the form which is different from other, the command refers to request, prevention refer to forbidding, the order must has commanded will, the prevention must has completed distaste. As for the amount of desist from the verb between one time or continuous, there isn't indication in this, it shouldn't be without presumption in the speech, besides the nature of forbidden thing, for example amount of desist in your saying ( don't drink wine) is different from amount of desist in your saying (don't speak), two pictures are sharing in desist indication, but they are different in its amount, as for the first refer to continuous of desist, and not to his will in the second. From theme which is about prevention came in religion conversation verses in Holy Quran :

(And do not argue with the People of the Scripture except in the best manner possible, except those who do wrong among them. And say, "We believe in what was revealed to us, and in what was revealed to you; and our God and your God is One; and to Him we are submissive). The verb (don't argue) is achievement verb, his form is prevention which is requiring fulfillment with desist about arguing with people of the book except the nice of the speech, he doesn't require from them desist from arguing at all, his obligated power lies in using softness in the arguing, without using intensity, he ordered with arguing with what is better, it is the duty which doesn't allow the other he said((and argue them with what is better))this is conversation from God to his prophet and all Muslims people to argue the people of the book from Jews and Christianity ((with what is better)) it mean only with nice of the speech for warning to the verses of God the better is the higher in advantage from one side accept to his mind and it might the higher in advantage from other side accept impression to him and it might prevent the two things, and (arguing) it mean opposition from doctrine in the way of argument in it, and in this indication to advantage of argument, because if it was ugly whatever the case, when he says ((with what is better))and he discovers the class of the speaker sympathy in the argument which lead to effective verb represents in convince them and effect on their thoughts, and their return to the mind in explanation arguments which displayed on them and then investigation the purpose from the speech, intensity in speech had to aversion and protest from it. As we notice in religions conversations verses in Holy Quran, that prevention combined with command and this return to the nature of the Holy Quran which connect legislative side and the system of transaction, worship and creeds, it has to be from command to performance all duties and 
then prevent from all forbidden things, it is rare that one of them separated from other, saying of God :

(And mention in the Scripture Abraham. He was a man of truth, a prophet. He said to his father, "O my father, why do you worship what can neither hear, nor see, nor benefit you in any way? O my father, there has come to me knowledge that never came to you. So follow me, and I will guide you along a straight way. O my father, do not worship the devil. The devil is disobedient to the Most Gracious. O my father, I fear that a punishment from the Most Gracious will afflict you, and you become an ally of the devil. He said, "Are you renouncing my gods, O Abraham? If you do not desist, I will stone you. So leave me alone for a while) These verses come in the text of speech about the invitation of Ibrahim (peace on him) to his father to worship God and leaving the worship of fetishes, this verses contain command verbs like \{remember, follow me, leave me \} also contain in about negation ((don't worship to fetishes)) for command verb \{remember , it is order to prophet Mohammed (peace be upon him) in remembering the strong of Ibrahim (peace on him) it may the reason for this prophet Mohammed (peace be upon him), his people and the people of his town didn't occupied with education and reading the books, if he told about the strong of Ibrahim (peace on him) as it happened, it would report about prescient and evidence to his prophecy, command verb came achievement verb his doing effect with proof the prophecy Mohammed (peace be upon him), besides another effect represents reply their claim on them Ibrahim was father of Arabs and most of them appreciation and they are closer to him and religion, it seem Almighty God say to them as you were imitators to yours fathers as you claim, saying of God: ( But they say, "We found our parents on a course, and we are guided in their footsteps) the most honored of their fathers Ibrahim (peace on him) they imitated him in leaving the worship of fetishes that you were from imitators or infer evidences which Ibrahim (peace on him) reminded about the corruption the fetishes that you were from inference people this is from one side, from the other side there were many from infidels in the time of prophet (peace be upon him) were saying :how we leave the religion of our fathers and predecessors, Almighty God reminded the story of Ibrahim (peace on him) to be evidence indicate to them, Ibrahim (peace on him) to be evidence indicate to them how Ibrahim left the religion of his father and undone it, in this preferred the right evidence on his father, and then after that the command and negation verb came (( I will guide thee to the way that is even and straight)) ((serve not Satan : for Satan is a Verb I against (Allah) most gracious ((guide)) is command verb which lead to achievement verb his power lies in guidance to the right way prevention from worship evil, it mean don't obey the evil because he is repel against the most gracious $\{\operatorname{God}\}$, so God repelled him with this adjective, God reminded this adjective to evil with he has from qualities and sins, God reminded the greatest sins of evil, disobedience to God isn't coming except the person who has weak opinion ((guide)) and ((serve not)) are coming to formation speech verbs which its achievement power represent in guidance, and what follow it from effective verb be clarified in breaking the evidences of his father in worship fetishes and then his invitation with mind evidence and guidance to the straight way in worship, invitation of prophet Mohammed (peace be upon him)to them, it is invitation to guide them because they are his people. The class of speaker which formulate the order with special from and leads with it the pronunciation conversation purpose and its function is certain communication, as we see, we find that command and negation are classes, and they are using according to deliberative text, which represent acknowledge the nature of command which meaning order picking or sufficiency from it, besides to the acknowledge characteristic of both sender and receiver and this what holy Quran clarified in religions conversation verses from order applications is the question, it mean ((is requiring)) science with some thing which isn't known before, it is information which they said in it, it request report what you don't have it mean question, which mean request understanding and of them who differed between them and he, said it is information what mention before it doesn't understand, if you ask about it again it was question, it is from construction methods which complete with special tools, it is tools according to the questioner about three types

1-It is using to ask for conception sometimes and ask for ratification at other and its tool is $\{$ Hamza

2-It is using to ask for ratification only and its tool $\{$ Do, Does, Did $\}$

3-It is using to ask for conception, it includes other tools.

Question was considered from applications which Searle called it (directives), its function to guide the receiver to answer it. The sender uses it to control the events and he uses it control on the mind of receiver and he use it to progress the speech towards what the sender wants, in holy Quran the question in it differs from the question in human speech, it isn't real question, the reason for this return to questioner doesn't know what he question about, he wants the answer to know about it .except God, he doesn't question from his creatures about something, because he is prescient, so question in holy Quran be reprimand and report and this expressed it with achievement power it might mean by this question from God to his believers holy Quran has many types of question which happened between prophets the followers of other religions one of them (They said, "Who did this to our gods? He is 
certainly one of the wrongdoers. They said, "We heard a youth mentioning them. $\mathrm{He}$ is called Abraham). These verses came in the story of prophet Ibrahim when he came out from town to his people to celebrate their feast, he beg the question with illness because he didn't want to be with them, after their exiting, he crashed the fetishes and he left axe in the neck of the biggest one of fetishes, when the people came back and saw what had happened to their God, they asked themselves by their saying ((who had done this to our God?)) this is question for the purpose of lament and investigation in the matter to get perpetrator this lead to their saying ((they said we heard young man reminds them)) ((he is from oppressors )) decision from them he is oppressor he should punish for his doing because he oppressed the God with aggression this is aggrandizement and oppress the people aggression to their right, and respect to their god sanctification their sacred and $\mathrm{He}$ oppressed himself with trespass to thing he doesn't have right. To do something he shouldn't to do this is their speech about prophet Ibrahim, saying verb came in the form of question (( who done this to our God)), achievement verb represent in knowing fetishes crusher his achievement power represent in getting on doer, as for effective verb which consequent from saying, he make it lesson in order not someone else to do something as he done from one side and to proof their power on other side from question which came from almighty God on the tongue of his prophet in his speech to the people of the book, ( Say, "O People of the Scripture, why do you reject the Revelations of God, when God witnesses what you do? Say, "O People of the Scripture, why do you hinder from God's path those who believe, seeking to distort it, even though you are witnesses? God is not unaware of what you do). Achievement speech verb which represent with question in ((why are you disbelieve, why are you repel )) fulfilled achievement power which represent in denial to them, their disbelief with verses of God and their rebuff people about faith with their acknowledge it is right, biggest which represent with prophet Mohammed (peace upon on him) who find his character Torah and Gospel, their acknowledge broadcast doubt in Muslim, especially the weaker faith of them, effective verb is reprimand to them.

These verses contain another order verb and it is calling, it mean :calling advocated to agree, or it request acceptance of who is invited to who called . It came in speech for purpose as : making relation with the other for invitation or conversation and for purpose which understanding from text, and in it encourage to attention to theme or with advocated, Dr. Mohammed Ahmad Nahla had taken out it

It from type of applications, so he said "as for the call doesn't consider speech verb, it doesn't consider about issue or it doesn't stand on reference and their appreciation to support deleted is unacceptable .and here we don't agree with him in the opinion because the call is achievement pronunciation leads to order and recall who is invited for going to who is called, and making receiver to answer sender besides it is entrance to other speech verbs from command, negative and question, also command is entrance to it and it unites with it to achieve speech verb, its purpose effective and achievement, from guidance speech verb because it simulates the receiver to reaction of speaker, and it occupied significant space in the text of Quran because it connects to command and negative, the call is the first speech verb, the speaker do it to be able after that to determine his aims, in returning to verses we find the repetition of calling ((the people of the book)) to attract their attention but not others it is achievement verb, its achievement power lies. In refuting their argument and their rebuke because Arab was respecting what the people of book has from science, so specialization the book with them and cancelled their value, it reveals to annulment what at others from gentiles and whom don't have the book for them .As for effective verb represent in encouraging people especially Muslims not to taking from them, their science are distorted and void, the command verb (say) has repeated, the repeat leads to effective verb representative in emphasis. The supplication consider from application verbs, it belongs to the speaker, besides its tense present and future, it mean command on the way of supplication and submission in the style of command be, if it emits from lower class to higher class, the different between it and command the first called for the verb is different from which prevents about it, it doesn't be unless from lower to higher, As for command is encouragement in doing and Preventing from leave it, is requiring that whom ordered from him inferior from who ordered for the supplication has three forms: command form, Negation form and report form :

( So We inspired him: "Build the Ark under Our observation and by Our inspiration. And when Our decree comes to pass, and the oven boils over, load into it two pairs of every kind, together with your family, except those of them against whom the word has already been pronounced. And do not speak to me concerning those who did wrong; for they are to be drowned. Then, when you and those with you are settled in the Ark, say, "Praise be to God, who has saved us from the wrongdoing people. And say, "My Lord, land me with a blessed landing, as you are the best of transporters). These verses came in the text of speech about the people of prophet Noah (peace on him) and what has done to him and how God rescued him from them, these verses have achievement verbs and its purpose is supplication, even the pronunciation ((claim)), supplication came in many positions to indicate that doing doesn't carrying out without supplication, from that positions ( $(\mathrm{Oh}$ my 
cord! Help me for that they accuse me of false hood)) his victory their destruction it had for this effective verb represent in Gods saying ((say praise be to Allah who saved us from oppressive peoples )), the effect of supplication is salvation from who lied him, then achievement verb came in the form of the call and the command, achievement power has moved to the supplication which receiver understands it when he hears it, in Gods saying ( $(\mathrm{Oh}$ my lord ! enable me to disembark with thy blessing for thou are the best to enable us to disembark)) his order that he call for God with supplication which is more important and more benefit to him, it is request that God descend him in the ship or in the earth when he exits from it, disembark which God bless him in it and give to him increase with goodness and he intercedes the supplication with compliment in his saying ((thou are the best to enable us to disembark)), also these verses contain another rhythm verb represent Gods saying: ((they are flooded )), it is achievement verb refers to rhythm from God, approved this, God talked about them in form, command is past, order of God be and it will be.

\section{3-information:}

Information mean "the saying which is requirement by it the proportion of known to known with negative and affirmation, and it is, the speech which enter in it honesty and lying, information is describing with honest if it agrees the case and it describes with lying if it doesn't agree with the case, and it sometime is describing with honest only or lying only it isn't for information but for purposes is outing from the text of sentence which emphasis its honest or lying, from this information of holy Quran, information of holy Quran have honest only because it is the speech of almighty God, even the information regardless of who say it, saying of Jew :Aziz son of God, and saying of Christianity :

Jesus son of God, speech which is lying because the reality lie and refuse it, even it honest and lying whence it is information the information is describing with honest and lying to reason which is out from phrase includes it within the deliberative because it doesn't study the pronunciations for itself but it studies its using in the speech, taking with consideration status and reference which is returning to it, circumstance of the receiver and whatever surrounds the speech .taking with consideration when telling the state of receiver, it may the first one who referred to the information is Almbrad when he was asked by Canadian philosopher that he finds in speech of Arab, much speech without meaning, they say $\{$ Abdallah is getting up\}then they say $\{$ that Abdallah is getting up $\{$ Abdallah will get up $\}$ and the meaning is one only, Almbrad answered him : no, different meanings when they say A Abdallah is getting up $\}$ it is information about his getting up, and \{that Abdallah is getting up $\}$ it is answer about question of the questioner and A Abdallah will get up it is answer about denies his getting up.

Information is verbs which describe facts and events in the outside world, and it enter with it what confer from the news of world, social issue and the religion issue and else, as for achievement purpose of it, it transferring the reality honest transferring, if honesty had achieved in transferring, it would have been achieved fidelity condition, and if fidelity condition achieved, the verbs would achieve a successful achievement .

Holy Quran presented the stories of prophets and their conversations with their people, and their facing to heavenly messages and this is from unseen news which prophet Mohammed didn't know about it nor his people, their information was coming from high level, its knowledge expanded the time and the place on its extension and informing about their stories consider as one of the Miracles which supports call of prophet Mohammed (peace be upon him) and honest of his prophecy, besides taking wisdom and sermon from it. (These are some stories from the past that we reveal to you. Neither you, nor your people knew them before this. So be patient. The future belongs to the pious). The information and stories of holy Quran form particular style, in spite of the existence style of the story called the historical story which aim to tell about the historical events without submission to phenomenon of \{possibility\} and \{potentiality\}, it submit to artificial elements that form plot which is surround with events, situations and people, as for the story of Holy Quran which we call it \{the practical story\} which concerns about transferring the fact in the way which appears aimed ideas from text, the difference between it and (artificial) returns in nature of effective, its size increases in the practical story\}, the emotion of the receiver remains sentimental more than artistic in it, because he realizes it deals with the reality without additions and possibilities and in this achieving conviction element to connect reality events with artistic methods and it give to it miraculous character. Religions conversations verses have news and stories prophet, their calling to their people, from this saying God : (And mention the brother of Aad, as he warned his people at the dunes. Warnings have passed away before him, and after him: "Worship none but God; I fear for you the punishment of a tremendous Day. They said, "Did you come to us to divert us from our gods? Then bring us what you threaten us with, if you are being truthful. He said, "The knowledge is only with God, and I inform you of what I was sent with; but I see you are an ignorant people. Then, when they saw a cloud approaching their valley, they said, "This is a cloud that will bring us rain." "In fact, it is what you were impatient for: a wind in which is grievous suffering. It will destroy everything by the command of its Lord. And when the morning came upon them, 
there was nothing to be seen except their dwellings. Thus We requite the guilty people). When almighty God gave types of evidences and proofs confirmation theism and prophecy, people of Makkh refrained from and they didn't care about, because they are busy with worldly pleasures so God told them the story of prophet Hood with his people tribe of add, they have more money and power than them, God ruled on them with torment because of their disbelief, and God told us how he tortured them with storm, and what happened of conversation between Hood and his people and their urge with torment, this story has came to take lesson from it and to leave their ignorance and their pertinacity, if they continue on their denial, the torment will descend on them, saying speech verbs have came news about people of prophet add his achievement power represents in intimidation the people of Makkh, Add had power and money, they didn't escape from punishment so how about them. As for effective verb is taking lesson from who precede them and to proof miracles of holy Quran in information about previous nations, besides entertainment prophet Mohammed (peace be upon him) and mitigation to his heart, the rejection of his people to accept the evidences and the proofs aren't the qualities of his people, but it is habit is happening in all previous nation and direction of identical in it from the words to the world, with fulfillment devotion and honesty conditions in transferring the information. From information is the negation it means : division of the all speech whether it is affirmation or negative when rejection person is honest in what he said, his speech mean negative speech and when he knew it is lying what he negated, it is odium in negative, that all odium negative without contrary it can call odium negative, because negative can not call negative odium . Some of them say that who published validity of negative about the thing validity of negative about it, so in this speech verb came in to cancel the speech which precede it, from it saying of almighty God : (And for their saying, "We have killed the Messiah, Jesus, the son of Mary, the Messenger of God." In fact, they did not kill him, nor did they crucify him, but it appeared to them as if they did. Indeed, those who differ about him are in doubt about it. They have no knowledge of it, except the following of assumptions. Certainly, they did not kill him ). The pronunciation came in pride and brag status in what they have done from sins, in their point of view is heroism, it is considering to them, and they assured with (( we are)), holy Quran made what they considered good deeds to them, the negative came in the pronunciation saying of God : (( they not kill him nor did they .crucify him but to them, he (the crucified) had been given the look of prophet Jesus)), his mandatory power represents in rejection what Jews have claimed, with its free from certainly, to be evidence on falsity of their claiming, it doesn't need confirmation, effective verb being in making it temptation to disbelievers, and guidance to believers about falsity of their claiming and from the negative the saying of God :

(Abraham was neither a Jew nor a Christian, but he was a Monotheist, a Muslim. And he was not of the Polytheists. ) After that Jews claimed that Ibrahim from them and Christianity claimed that Ibrahim from them, God protested on them, that the Torah and the gospel have descended after Ibrahim, how is it possible that he is Jewish or Christian, making the lawsuit without proof isn't permissible in the mind, how it is possible making the after appearance of its corruption, then God denied of his being Jewish or Christian, because it is disparagement characters in holy Quran, as distorted from their way, but he was Hanafi which mean he is leaving all religion except Islam, by using the tools \{not $\}$ and after it $\{$ did $\}$, in saying of God ((he was neither a Jew nor a Christian )) and ((and he was not of the polytheists )) the negative become stronger and tougher to achieve honesty condition in transferring from one side and separation the words from the world in the speech which preceded the negative and the direction of the conformity from the words to the world after negative the negative speech verb resulted achievement power which represent in annulment the previous claims, as for effective verb represents in Islam is more correct than other religions, because it is extension to the religion of prophet Ibrahim (peace on him), so it isn't distorted and the first to follow.

\section{4-the obligations:}

It is speech verb which the speaker means by it doing something willingly to the listener in the future and he is sincere in his speech, and he is insistent on fulfillment with it . it contains: the promise intimidation pact, security, warning and other . and it participates with applications toward conformity and both of them the direction of conformity in it from the world to the words both of them differs in the reference, the reference in the obligations (the speaker), as for in applications is (listener). The promise and intimidation consider the most prominent obligation verbs, because it returns to the speaker, he is able person on fulfillment with it and achievement it, it means by it: the promise, the appointment, intimidation and time are resources, I promise him, he promises is exceeding to objects, it can in it exclusive on one of them, the promise in goodness and the intimidation in evil I promise him it doesn't be except in evil, it saying I promise him with evil and it doesn't say I promise him evil, and the truth of the promise is telling about goodness which teller achieves in the future or evil, and the difference between the promise and intimidation, that intimidation in the evil especially, as for promise in the goodness and evil and when it released, it would specialize with goodness. From 
what it came in religions conversation verses promise and intimidation, saying of God:

(Those who disbelieved said to their messengers, "We will expel you from our land, unless you return to our religion." And their Lord inspired them: "We will destroy the wrongdoers."). And it might from naughtiness of disbeliever and their oppression, their warning to their prophets and believers, their threat with expulsion them from their country after they couldn't speak with them unless they return to them and this intimidation with evil to prophet, almighty God confronted it with promise and intimidation, the intimidation when God swear that he will damn them, and the promise was for the prophets and believers that he will stay them the earth after destruction of disbelievers, and this is penalty for whom fears status of God and his threat, threat speech verb is coming from speakers, the first speaker are disbelievers and their intimidation doesn't have conformity from the world to the words, because the speaker can not execution his intimidation, for this devotion has denied, as for the second speaker is almighty God who confronted their intimidation, making it without importance, he assured it with swear ((to destroy oppressive)) and he promised them, living their place effective verb represents in reassure the prophets and who believed with them, that God reward and supports them, the direction of conformity in it from the world to the words. And from intimidation which and specialized with it the people of the book, saying of God:

(O you who were given the Book! Believe in what We sent down, confirming what you have, before We obliterate faces and turn them inside out, or curse them as We cursed the Sabbath-breakers. The command of God is always done.). In this verse speech the people of the book and it doesn't include them all, so God said (( those who have received the book)). This is on us which is particular to those who was knowing the whole Torah, and who was like this, so he is knowing the evidences which are referring to the prophecy of Mohammed (peace be upon him), because Torah was including all these evidences, so that God said : ((confirming that which is $\{$ already $\}$ with you)) which mean is confirming to the verses which are existing in Torah, which are referring to the prophecy of Mohammed (peace be upon him), and if the knowledge was happened, this was disbelief downright obduracy. God ordered them with affirmation in believing prophet Mohammed (peace be upon him), and that God joints strong intimidation with this, when it happened, he teach them their disbelief with it become excuse on them, and evidence on their obduracy and their interesting on the falsehood, as for their threat with damnation like the people of Saturday, it is from obligation verbs which represent intimidation and threat with descending the punishment on them, as for effective verb which represents in obligating them to believe the prophecy of Mohammed (peace be upon him). And from the obligations . the treaty, it is obligation between two sides or more, and it came in religions conversation verses, saying of God :

(Say, "O People of the Book, come to terms common between us and you: that we worship none but Allah, and that we associate nothing with Him, and that none of us takes others as lords besides Allah." And if they turn away, say, "Bear witness that we have submitted."). The speech has came to all people of the book, the prophet Mohammed called them to gather on word to work with it and publish it, their calling to the people of the book, in it there is kind of kindness to the heart of the receiver, the situation is situation of inviting to conciliate between sides and communication to treaty. Which mean by this Quran, Thora and gospel are concurrent in invitation to it, and it is monotheism word. Obligated monotheism and refuse partners and don't taking lords without Almighty God, it is invitation to practical monotheism, which mean by it (( that we worship none but Allah and that we associate no partner with him, and that some of us take not others for lords besides Allah)). The speech is preceding with negative, refusing polytheism, and achievement power represents in contracting treaty with all religions and the agreement on worship God, as for effective verb is amity in invitation the people of the book to contract the agreement, the direction of conformity in it from the world to the words, with achievement devotion condition to obligate all sides in the future. And in this we find that obligation verbs achieved the achievement purpose to it, it is belong to the speaker who is capable of achieving it, specially which connecting with God and his prophets, as for which is connecting to other side, it doesn't achieve its purpose, because it doesn't have ability on achieving it, even it seems to him, he able on this, obligations came to refer on the present and the future identical to its conditions .

\section{5-the expressions:}

It is type of direct speech verbs, it contains the speech verbs and what includes from styles and terms which by it the speaker expresses his feeling in the case the satisfaction, anger, success, failure and others . these verbs don't limited on the special events of the speaker, but exceed to what happened to the people who participates in the verb and it effects psychologically and sentimentally on the speaker and it is entering in it : thanks verb congratulation verbs, sympathy verbs, regret verbs, sorrowfully, wish, love, hate, anger, apology and else . it doesn't have direction to conformity, it is compensated for it devotion condition, when it achieved, the verb completed successfully. We find in religions conversation verses in holy Quran many speech verbs which express about psychological and 
sentimental cases which the prophets felt it and imagine the reality which they were living in it, from this saying of God :

(We sent Noah to his people. He said, "O my people! Worship God; you have no god other than Him. I fear for you the punishment of a tremendous Day." The dignitaries among his people said, "We see that you are in obvious error." He said, "O my people, I am not in error, but I am a messenger from the Lord of the Worlds." "I deliver to you the messages of my Lord, and I advise you, and I know from God what you do not know Do you wonder that a reminder has come to you from your Lord, through a man from among you, to warn you, and to lead you to righteousness, so that you may attain mercy?").

In this verses is telling from almighty God about the story of prophet Noah (peace on him) and we find the kindness in his invitation to them, beginning with the call, he called them (( O my people $))$ the calling has warning power to make them feel that he Cares about them because they are his people, in meditation to this calling, it appears he doesn't call people unless God tortured them, it is call the torment of God, what assured that the way of calling - Here is coming to warn to the importance of the matter which they invited for it and it is from kindness with them in order to make their hearts respond to the great matter which is worship God, so we see the prophets invite their peoples with what they feel from alliance with them and this by adding pronunciation people to conscience of the prophet to close their souls, and order them in worship God, he clarified the reason for this, the worship mean submission in the heart in higher level of submission, it has a greatest blessings, so no one deserve the worship except God, there is no God nor idol except him (Allah)and he afraid on them ((the punishment of tremendous)), the torment is continuous pain on them, it might another punishment, but it means here the painful punishment on what it was from sins, he didn't make his fear on them with doubt but telling them the torment will be on them, if they don't accept his invitation and his advises he said (( I advise you)). The advise is sincerity of intention from corruption in treatment, (advise) is opposite in cheating in the work, cheating doesn't be except with bad intention, prophet Noha (peace on him) expressed his feeling toward the situation of his people and their reality, they are worshipping fetishes, he expressed his fear on them, the speech verbs (( I fear for you )) and ((I advise you )), and hopefulness in (( so that you may attain mercy?)) it has achievement power represents in advising and guidance, it expresses what he feels toward his people from kindness, clemency and compassion on them, in them there is his house hold who doesn't believe God, he spoke with his son after the flood in other verse, with saying of God:
(And it sailed with them through waves like mountains, and Noah called to his son who was apart [from them], "O my son, come aboard with us and be not with the disbelievers." [But] he said, "I will take refuge on a mountain to protect me from the water." [Noah] said, "There is no protector today from the decree of Allah, except for whom He gives mercy." And the waves came between them, and he was among the drowned.) as for effective verb refers to sympathy and mitigation about prophet Mohammed (peace be upon him) and encourage him on patience and constancy, from natural of nations is denial prophet and messengers, if their invitation conflicts with their interests. From the expressions is wish, wishing the thing : want it, is requesting something which the self love and desire in it, but he doesn't please to get it, as for hopelessness in saying of God:

(But if bounty comes to you from Allah, he will surely say, as if there had never been between you and him any affection. "Oh, I wish I had been with them so I could have attained a great attainment."). Or it may for which mean it is possible and don't coveted in getting it . as the saying of God:

(So he came out before his people in his adornment. Those who desired the worldly life said, "Oh, would that we had like what was given to Qarun. Indeed, he is one of great fortune."). The difference between it and the please, the wish enters in impossibilities and the please enters in possibilities, its tools are: would that, do you, albeit, might, may be . From verses which the wish came in it, saying of God:

(It was said, "Enter Paradise." He said, "I wish my people could know Of how my Lord has forgiven me and placed me among the honored."). The wish is coming on the tongue of the friend of Yasin (Habib Bin Israel Najar) after his people hit him with their feel till he died, say to him enter the heaven, he wishes that his people who scorned him knew the recompense, forgiveness and status which he reached by his faith, to wish such as it. The wish is expression verb which refers what he feels toward his people, his achievement power represent in wishing his people knew situation which he reached to it. Effective verb refers to encourage on the work as he worked, there isn't direction in it for conformity with achieving devotion condition in the wish, from the case which indicated psychological emotion of the prophets, the story of prophet Ibrahim (peace on him) with his father, this story repeated in many verses, it has came in the poets Sara verses $(69-84)$ and in the prophet Sara verses $(52-70)$ and in Zukhruf Sara verses $\left(26_{-} 28\right)$ and in Mariam Sara verses (41_48) it might the more 
clarification to human emotion previous Soras almighty God said: (And mention in the Book [the story of] Abraham. Indeed, he was a man of truth and a prophet. [Mention] when he said to his father, "O my father, why do you worship that which does not hear and does not see and will not benefit you at all? $\mathrm{O}$ my father, indeed there has come to me of knowledge that which has not come to you, so follow me; I will guide you to an even path. O my father, do not worship Satan. Indeed Satan has ever been, to the Most Merciful, disobedient. O my father, indeed I fear that there will touch you a punishment from the Most Merciful so you would be to Satan a companion [in Hellfire]." [His father] said, "Have you no desire for my gods, O Abraham? If you do not desist, I will surely stone you, so avoid me a prolonged time. [Abraham] said, "Peace will be upon you. I will ask forgiveness for you of my Lord. Indeed, He is ever gracious to me. And I will leave you and those you invoke other than Allah and will invoke my Lord. I expect that I will not be in invocation to my Lord unhappy."). Ibrahim called is father (( O my father)), because in that politeness notification and lobbying the self, this from what the status require, because its speech from son to his father about something great from one side and, speech for invitation from other side, so the sentence is coming with two achievement purpose, the first represents in calling the relative with tool of distance person, warning to the great of the matter its importance and the second is politeness and pity with father. The effective verb represents in lobbying the selves with nice speech, his father faced him with calling which refers to the feeling of anger (( $\mathrm{O}$ Ibrahim? If you do not desist, I will stone you . so leave me alone for awhile )), here the calling came with the name of the son without pity or love notification and with stoning threat and expulsion, as for the calling in the speech of Youssef and his father Yacoub (peace be on them) in the saying of God: ( [Of these stories mention] when Joseph said to his father, "O my father, indeed I have seen [in a dream] eleven stars and the sun and the moon; I saw them prostrating to me." He said, "O my son, do not relate your vision to your brothers or they will contrive against you a plan. Indeed Satan, to man, is a manifest enemy.). Here the speech from father to his son (( $\mathrm{O}$ my son $)$ ) which refers to the pity of the father toward his son, and it might the reason for this the difference in religions between the father and his son in the speech of Ibrahim and his father, if we compare it with the speech of Youssef and Yacoub (peace be on them). The summarize from this religions conversations verses discovered the human self cases and what happened to it from emotions, it gave us complete imagine about the case of prophet and messengers in their invitation to their people, the psychological reaction to their people and its effectiveness in the prophets, the purpose of it achieved in expressing about the cases in the shape which available in it devotion condition and what it leaves from effect in every one who repels to invitation from being patient with what happened to other nations.

\section{Conclusion and result:}

So that communication is linguistic science which searches in how the sender use the language in achieving higher level of successful communication with receiver, then of signs, it was the most suitable to study religions conversation in holy Quran, because it is communication active which standing on transferring linguistic efficiency to achievement communication efficiency. The conversation consider as important means of invitation means to worship God and follow the right religion, it clarifies by it the right picture to dogmas of religion and its rule and its decency and it including what the prophets done with their people or with all people of the religions from conversation in the different ways and in different styles and it all have one name (religions conversation) rhythm happened change in current situation it has the conditions which students defined it . it has intent and reporting and its achievement power changed accordance to the class of the speakers and their psychological state. Command verb was in religions conversation : verses significantly, it led achievement function which followed by effect on the receiver, especially the verb(say) it has repeated in the verses significantly and its coming shaped continuous of speech verbs who pronounced it God by Gabriel (peace be on him) and who pronounced for is prophet Mohammed (peace be upon him), it became pronounced after received the pronunciation, this verb (say) is command verb from achievement verbs which is followed by other verbs, especially application achievement verbs which represents with command, the call and the question. Command and call shaped entrance to other speech verbs the speaker uses to reach with it to other purposes, from command, negative and question, it gather with other achievement verbs to achieve speech verbs, achievement and effective purpose for it. The obligation verbs fulfilled the achievement purpose for it, it belongs to the speaker who able an achieving, especially which connected to almighty God and his prophet (peace be upon him)as for which connected to other side, it doesn't achieve its purpose Because he doesn't has the ability on achieve it, even it seems to him, he has ability on this, the obligations came to refer to the present and the future identical to its conditions. Religions conversations verses in the expression verbs, it discovered about human psychological cases and what it has from emotions, it presented a total imagine about the cases of prophets and messenger 


\begin{tabular}{|c|c|c|c|c|c|c|}
\hline Impact Factor: & $\begin{array}{l}\text { ISRA (India) } \\
\text { ISI (Dubai, UA } \\
\text { GIF (Australia) } \\
\text { JIF }\end{array}$ & $\begin{array}{c}=1.344 \\
=0.829 \\
=0.564 \\
=1.500\end{array}$ & $\begin{array}{l}\text { SIS (USA) } \\
\text { PИНЦ (Russia } \\
\text { ESJI (KZ) } \\
\text { SJIF (Morocce }\end{array}$ & $\begin{aligned}= & 0.912 \\
= & 0.234 \\
= & 1.042 \\
= & \mathbf{2 . 0 3 1}\end{aligned}$ & $\begin{array}{l}\text { ICV (Poland) } \\
\text { PIF (India) } \\
\text { IBI (India) }\end{array}$ & $\begin{array}{l}=6.630 \\
=1.940 \\
=4.260\end{array}$ \\
\hline
\end{tabular}

in their invitation to their people, and their psychological reaction to their people and its effect in messengers, the purpose of it has achieved in the expression about these cases in the form which available in it devotion condition, and what it leave from effect in every one who repels to invitation from being patient with what happened to other nations .

\section{References:}

1. (2016) Communication at Arab scholars, Dr. Massoud Al_Sahroie :40.

2. (2016) Linquistic works circle, Dr.Shakri Al_Mabkout:167.

3. (2016) Speech verbs theory, Osten :115.

4. (2016) Communication at Arab scholars, Dr. Massoud Al_Sahroie:5.

5. (2016) Communication at Arab scholars, Dr. Massoud Al_Sahroie:41_42

6. (2016) The dimension of communication in the speech of Quran, Dr.Qudoor Imran :57

7. (2016) Communication at Arab scholars, Dr.Massoud Sahroie:41_42.

8. (2016) The dimension of communication in the speech of Quran, Dr.Qudoor Imran: 58_59.

9. (2016) The study of speech verbs in Holy Quran, P. Abu Guerrouma Hakima, the speech magazine : 11 .

10. (2016) New prospect in modern linguistic research, Dr. Mahmoud Ahmad Nahla :111

11. (2016) The study of speech verbs in Holy Quran, P. Abu Guerrouma Hakima, the speech magazine :11_12

12. (2016) The new dimension in the modern linguistic research, Dr. Mahmoud Ahmad Nahla:98_99

13. (2016) Al_Imran Soura :82_86

14. (2016) Yonis Soura:31_32

15. (2016) The keys of unseen Al Razi:17_91

16. (2016) New prospect in modern linguistic research Dr. Mahmoud Ahmad Nahla: 100_104

17. (2016) The total, Al Kafoi :176_178

18. (2016) The picture of command and negative in Holy Quran, Dr. Mahmoud Twafiq Mahammed Sead :9

19. (2016) Astrategies of the speech, Abud Al Hadi Al Shahri :343_344

20. (2016) Dictionary of rhetorical terminology and its development, Dr. Ahmad Matloub :313_314

21. (2016) Astrategies of the speech, Abou Al Hadi Al Shari :342

22. (2016) The dimension of communication in the speech of Holy Quran, Dr.Qudoor Imran:174_175

23. (2016) Al Anam Soura :10_11
24. (2016) The keys of unseen, Al Razi :12/ 172_173

25. (2016) Al Imran Soura / 72

26. (2016) The dimension of communication in the speech of Holy Quran, Dr.Qudoor Imran:180

27. (2016) Dictionary of rhetorical terminology and its development, Dr. Ahmad Matloub: 3/344

28. (2016) Command styles at grammatical and rhetorical, Dr. Qis Ismael Al Ousie :479

29. (2016) Dictionary of rhetorical terminology and its development, Dr. Ahmad Matloub:3/344

30. (2016) Command styles at grammatical and rhetorical, Dr. Qis Ismael Al Ousie:472

31. (2016) The Spider Soura $/ 46$

32. (2016) Aletabin Explanation of Holy Quran, Al Shak Al Twassie :8/214

33. (2016) The study of speech verbs in Holy Quran, Abu Quroma Hakima speech magazine: 14

34. (2016) Mariam Soura /41_46

35. (2016) Al Zakraf Soura $/ 23$

36. (2016) Keys of unseen, Al Razie :223_226

37. (2016) The communication at Arab scholars, Dr. Massoud Al_Sahroie :106

38. (2016) Dictionary of rhetorical terminology and its development, Dr Ahmad Matloub:1/118

39. (2016) Construction styles in Arabic Grammar, Abd Al Slam Mohammed Haroun:18_21

40. (2016) The study of speech verbs in Holy Quran, Abu Quroma Hakima speech magazine: 14

41. (2016) Command styles at grammatical and rhetorical, Dr.Qis Ismael Al Ousie:308

42. (2016) The Prophets Soura /59-60

43. (2016) Scales in Explanation of Quran, Al Tabtabai : $14 / 301$

44. (2016) Al Imran Soura/ 89_99

45. (2016) Dictionary of rhetorical terminology and its development, Dr. Ahmad Matloub:3/326

46. (2016) Metaphor of calling and its reality and its purposes in Quran speech, Dr. Dafir Bin Krman Al Amrie, academy of Imam Al Shatbie for Quran studies magazine, sixth issue:106

47. (2016) The new prospect in modern linguistic research, Dr. Mahmoud Ahmad Nahla :114 


\begin{tabular}{|c|c|c|c|c|c|c|}
\hline Impact Factor: & $\begin{array}{l}\text { ISRA (India) } \\
\text { ISI (Dubai, UAI } \\
\text { GIF (Australia) } \\
\text { JIF }\end{array}$ & $\begin{array}{l}=1.344 \\
=0.829 \\
=0.564 \\
=1.500\end{array}$ & $\begin{array}{l}\text { SIS (USA) } \\
\text { PИНЩ (Russia } \\
\text { ESJI (KZ) } \\
\text { SJIF (Morocco }\end{array}$ & $\begin{aligned}= & 0.912 \\
= & 0.234 \\
= & \mathbf{1 . 0 4 2} \\
= & \mathbf{2 . 0 3 1}\end{aligned}$ & $\begin{array}{l}\text { ICV (Poland } \\
\text { PIF (India) } \\
\text { IBI (India) }\end{array}$ & $\begin{array}{l}=6.630 \\
=1.940 \\
=4.260\end{array}$ \\
\hline
\end{tabular}

48. (2016) The study of speech verbs in Holy Quran, P. Abu Quroma Hakima Speech magazine: 12

49. (2016) Metaphor of calling and its reality and its purposes in Quran speech, Dr.Dafir Bin Krmam Al Amrie, academy of Imam Al Shatbie for Quran studies magazine, sixth issue:202

50. (2016) The dimension of communication in the speech of Holy Quran, Dr. Qudoor Imran:227_235

51. (2016) The end of Conciseness, Al Razie :37

52. (2016) Semantic rhetorical and criticize study meanings, Dr. Bassiouni Abd Al Ftah Feud:364

53. (2016) Analysis of Quran and its data, Mohi Al Dean Al Droish :3/324

54. (2016) Construction styles in Arabic grammar, Abd Al Slam Mohammed Haroun :16

55. (2016) Believers Soura:25_29

56. (2016) The prospector, Al Elzimkhcri :4/228

57. (2016) Dictionary of terminology, Al Kfwi:414

58. (2016) Semantic rhetorical and criticize study meanings, Dr. Bassiouni Abd Al Ftah Feud:42

59. (2016) Key of sciences, Alskaki :171

60. (2016) The new prospect in modern linguistic research, Dr. Mahmoud Ahmad Nahla:103

61. (2016) Hood Soura/49

62. (2016) Artistic studies in the stories of Holy Quran, Dr. Mahmoud Al basstanie:7_8

63. (2016) Al Ahqaf Soura:21_25

64. (2016) Keys of unseen, Al Razie:28/26_28

65. (2016) Scineses of proofs in Quran, Al Zrakashie :2/375_376

66. (2016) Women Soura:157_158

67. (2016) Aletbian in explanation of Quran, Al Tosie :3/379

68. (2016) Al Imran Soura:67

69. (2016) The statement compound in explanation of Quran, Al Tbursie:2/177_178

70. (2016) The new prospect in modern linguistic research, Dr. Mahmoud Ahmad Nahla:104

71. (2016) The statement compound in explanation of Quran, Al Tubrsie:1/170

72. (2016) Arrest on missions definitions, $\mathrm{Al}$ Mnawe :729

73. (2016) Ibrahim Soura /13-14

74. (2016) Aletbian, Al Tosie:6/281_282

75. (2016) Women Soura:47

76. (2016) Keys of unseen, Al Razie:10/124

77. (2016) Al Imran Soura :46

78. (2016) The statement compound, Al Tabatabai :3/283_285

79. (2016) The new prospect in modern linguistic research, Dr.Mahmoud Ahmad Nahla:104

80. (2016) Al Aruf Soura:59_63

81. (2016) Metaphor of calling and its reality and its purposes in Quran speech, Dr.Dafir Bin Krmam Al Amrie, academy of Imam Al Shatbie for Quran studies magazine, sixth issue:212_213

82. (2016) Aletbian, Al Tosie :4/434_437

83. (2016) Hood Soura:42_43

84. (2016) Women Soura: 73

85. (2016) Stories Soura:79

86. (2016) Detailed dictionary rhetorical sciences, Dr. Enam Nawal Akkaoui: 428. Dictionary of rhetorical terminology and its development, Dr. Ahmad Matloub :2 /353_354.

87. (2016) Science of meanings, Dr. Bassiouni Abd Al Ftah Feud:420_422

88. (2016) Yasin Soura:26_27

89. (2016) The prospector, Elzimkhcri :5/171_172

90. (2016) Mariam Soura:41_48

91. (2016) Youssef Soura:/4_5

92. (2001) Construction styles in Arabic Grammar, Abd Islam Mohammed Haron. Al Khanji, Cairo_Egypt, 2001.

93. (1988) Command styles at grammarian and rhetorical, Dr. Qis Ismael Al Ousie, Ministry of High Education and scientific research, Baghdad University, wisdom house for republish and translation, Baghdad_Iraq, 1988.

94. (2004) Strategies of the speech_approach communication linguistic, Abd Al Hadi bin Dafr Al Shahri, United Dar the new book, Beirut_Lebanon, 2004.

95. (1428) Analysis of Quran and its information, Mohi Al Dean Drouish, publications of Zoie Al Qurba, Qum_Iran, 1428.

96. (2002) The new prospect in the modern linguistic research, Dr. Mohmaud Ahmad Nahla, Dar University Knowledge, Egypt, 2002.

97. (1391) The proof in Holy Quran, Abu Abid Allahh Hmad Bin Bhadr Bin Abid Allah Al zrakashie (794), investigation :Mohammed Abu Al Fadal Ibrahim, Knowledge Dar, Beirut_Lebanon, 1391.

98. (2012) The communication dimension in the speech of Quran which refer to Israelis, Dr.Qdoor Imran, The world of the new book for republish, Irbid_Jordan, 2012.

99. (2016) Altbian in Explanation of Quran, Abu Jafar Mohammed Bin Hasan Al Tousie (460), Presented to it: Al Shakh Agha Bzrak Al Thrani, Correction: Ahmad Habib Al Amele, Dar restoration of Arabic Heritage, Beirut _ Lebanon .

100.(2005) The communication at Arab scholars _communication study to the phenomena of speech verbs in Arab heritage, Dr. Massoud Al Sahrawi, Dar Al Talia for republish, Beirut _ Lebanon, 2005 . Missions definition, Mohammed Abd Al Raoof Al mnawie 


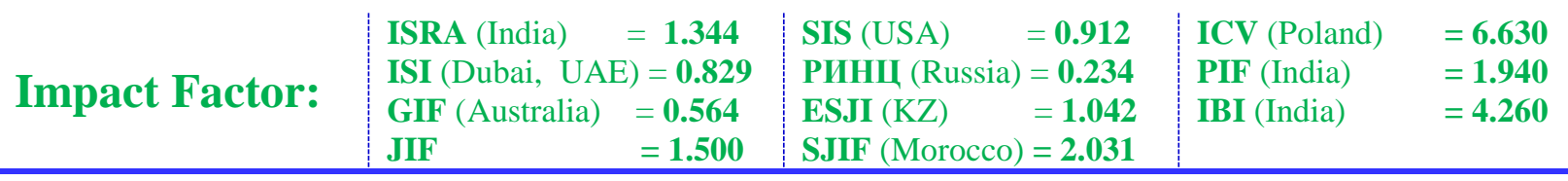

101.(1031) investigation : Dr. Mohammed Radwn Al Daia, Dar of modern idea, Beirut - Lebanon , 1410.

102.(2010) Circle of linguistic works from suggestions, Dr. Shakri Al Mabkoot, United Dar of new book, Beirut _Lebanon, 2010.

103.(2013) Artistic study in the stories of Quran, Dr. Mohamoud Al Bstanie, Al Blaka Dar for republish, Beirut_Lebanon, 2013.

104.(2016) The study of speech verbs in Holy Quran, P. Bou Qourma Hakima, republished research in the speech magazine, publications of laboratory analysis of the speech

105.(2008) Moulod Al Mamri university, Dar Amal for copy and republish, Algeria, the third issue, 2008.

106.(1993) The picture of command and negative in Holy Quran, Dr. Mahmoud Twafiq Mohammed Sad, Al Amana printing house, Cairo-Egypt, 1993.

107.(2010) Semantic science rhetorical study to the meanings, Dr. Bassiouni Abd Al Ftah Feud, Al Maktar establishment for republish, 2010.

108.(1998) Al Kshaf for facts Goumd Al tnazel and Auoon Al Qawel in Wjooh Al Taweel, Jar Allah Abu Al Qassim Mahmoud Bin Amar El Zmikhcrie (583), investigation :Al Shakh Adal Ahmad Abid Al Mwojoud and Al Shakh Ali Mohammed Maod and Dr.Fathie Abid Al Rahman Ahmad Hajazie, publisher Al Obeikan officer, Riyadh_Saudi Arabia, 1998 .

109.(1998) Al Kleit dictionary in terms in linguistic differences, Abu Al Bka Ayoub Bin Mausa Al Hassine Al Kfawe (1094), printed it and put its references :Dr. Adnan Drowish, Mohammed Al Massrie, Al Reasala establishment, Beirut _Lebanon, 1998.

110.(1429) Metaphors of calling and its reality and its purposes in Quran speech, Dr. Dafar Bin Gmran Al Amrie, published research in academy of Imam Al Shatbie magazine about Quran studies, sixth issue, 1429.

111.(2008) Compound statement in explanation of Quran, Abu Ali Al Fadal Bin Hassin Al Tbrasie (560), investigation :Hashim Al Rassulie Al Mahlalatie, Arabic History establishment, Restoration Arabic heritage Dar, 2008.

112.(1986) Rhetorical terminology dictionary and its development, Dr. Ahmad Matloob, house printed Al Mjma Iraqi scientific, Baghdad Iraq, 1986.

113.(1996) Detailed dictionary in science of rhetorical Al bdea and statement and meanings, Dr.Anam Nawal akawie, review: Ahmad Shmas Al Dean, scientific books Dar, Beirut_ Lebanon, 1996.

114.(1981) Unseen keys or the big explanation, Mohammed Fakher Al Dean Bin Dhia Al Dean Amar Al Razie (606), Al fakr Dar, Beirut _Lebanon, 1981.

115.(1987) Sciences key, Abu Al yacoub Youssef Bin Abie Beakr Bin Mohammed Bin Ali Al Sakakie (626), set and comment it : Naem Zarzoor, scientific books Dar, Beirut_ Lebanon, 1987.

116.(1997) The scales in Quran explanation, Mohammed Hussien Al Tabtabaie, Al Alamie establishment for publications, Beirut Lebanon, 1997.

117.(1991) The theory of speech verbs how we achieved things with words, Ostien, translation of Abd Al Qadar Qanienie, the east Africa Dar, Al Dar Al Beada _ Morocco, 1991.

118.(1317) The end of conciseness in awareness of miracles in rhetorical sciences in Holy Quran, Faker Al Dean Mohammed Bin Amar Al Razie (606), literatures print house, Cairo_ Egypt, 1317. 